\title{
Factors Influencing the Satisfaction of International Postgraduate Students in the Malaysian Context-A Literature Review and A Proposed Model
}

\author{
Mumtaz Ali Memon ${ }^{1}$, Rohani Salleh ${ }^{1}$, Mohamed Noor Rosli Baharom ${ }^{1} \&$ Haryaani Harun ${ }^{1}$ \\ ${ }^{1}$ Department of Management and Humanities, Universiti Teknologi PETRONAS, Perak, Malaysia \\ Correspondence: Mumtaz Ali Memon, Department of Management and Humanities, Universiti Teknologi \\ PETRONAS, Bandar Seri Iskandar, 31750 Tronoh, Perak, Malaysia. E-mail: mumtazutp@yahoo.com
}

Received: July 18, 2014 Accepted: September 12, 2014 Online Published: October 29, 2014

doi:10.5539/ies.v7n11p76 URL: http://dx.doi.org/10.5539/ies.v7n11p76

\begin{abstract}
The Malaysian government is continuously striving to develop the country to become a regional education hub. Hence, higher learning institutions, especially universities, are becoming the centre of attention in order for Malaysia to achieve its desired status. Although the number of international postgraduate students in Malaysia has progressively increased, the country still needs an annual growth of 13.5 per cent to attain the target of 150,000 international students by 2015. Previous studies have reported that student satisfaction can lead to attracting new students and retaining the existing ones. Hence, it is essential for Malaysian universities to understand the factors that influence the satisfaction of students. Despite its importance, less attention has been given to the experiences and satisfaction of students in higher learning institutions in Malaysia. The key objective of this paper is to conduct a comprehensive review of the literature and develop a conceptual model that integrates several antecedents that are theoretically linked to student satisfaction. The proposed conceptual model suggests that the internal and external environment of a university, and the feedback of research supervisors are the key factors that influence the level of satisfaction among international postgraduate students. Finally, recommendations for future studies are proposed.
\end{abstract}

Keywords: student satisfaction, internal and external environment, feedback, higher learning institution Malaysia

\section{Introduction}

The Malaysian government has been striving to develop the country to become a regional education hub. To achieve this regional status, Malaysia has focused on promoting its higher learning institutions, particularly universities. Following the 9/11 disaster, students, particularly from the Middle East, Africa and other Muslim countries (e.g., Pakistan and Bangladesh), have increasingly considered Malaysia as their top choice for tertiary education, especially for postgraduate studies. This change in preference has increased the number of international postgraduate students pursuing studies in Malaysian universities.

In 2002, the total population of international students in Malaysia was 27,872 (Horany \& Hassan, 2011; Yousif \& Chelliah, 2010). This number increased significantly to 86,000 in 2011 (Edvantage Asia One, 2011). In the Malaysian higher education sector, both public and private institutions are well established; hence, a high degree of competition exists among these institutions. Despite the growing demand, the Malaysian Minister of Higher Education recently indicated the need for an annual growth of 13.5 per cent for the country to attain its target of 150,000 international students by 2015 (Edvantage Asia One, 2011). Hence, local universities are now striving to increase the number of international students, and, as such, it is imperative that student satisfaction is met (Arambewela \& Hall, 2013), as, nowadays, students prefer institutions that provide unique and memorable learning experiences (Ravindran \& Kalpana, 2012). Thus, it is essential that local universities improve the services they offer to increase the satisfaction of their international students (F. Alam, Q. Alam, \& Rasul, 2013).

Recently, the subject of student satisfaction has received much attention and has become one of the major goals of all higher educational institutions (Temizer \& Turkyilmaz, 2012). Student satisfaction is defined as the satisfaction of students with their overall educational experience, which reflects their primary goal of obtaining their educational qualifications from the host country (Arambewela \& Hall, 2013, p. 973). The growing 
emphasis on student satisfaction has been driven by the fact that a higher level of student satisfaction can lead to a stronger competitive position, which will attract new students and maintain the existing ones. In fact, student satisfaction has been acknowledged to be a critical indicator of word-of-mouth, retention and loyalty (Temizer \& Turkyilmaz, 2012). Undoubtedly, as primary customers, student satisfaction is critical to the existence of any higher education institution (Ibrahim, Rahman, \& Yasin, 2014). Supporting this view, Jalali, Islam, and Ariffin (2011) emphasized that for Malaysian universities to attract new students and retain the current ones, focus must be given to student satisfaction. Given these points, it is imperative that Malaysian higher education institutions listen to their customers' (students) needs and find a means to satisfy them.

Although customer satisfaction has been extensively discussed in different settings with different antecedents and outcomes (e.g., Anderson \& Fornell, 2000; Crotts, Mason, \& Davis, 2009; Fornell, Johnson, Anderson, Cha, \& Bryant, 1996), little attention has been paid to the experiences and satisfaction of students in higher education (Elliot \& Healey, 2001; Lizzio, Wilson, \& Symons, 2002; Symons, 2006; Ting, 2000). Most of the available studies on the subject matter have been conducted in the Western educational context (Parahoo, Harvey, \& Tamim, 2013). In particular, these studies were conducted in countries, such as the UK and USA ( $\mathrm{Li}, 2005$; Maggs, 2014), Australia (Arambewela \& Hall, 2008, 2013), the Netherlands (Kleijn, Meijer, Pilot, \& Brekelmans, 2013; Mainhard, Rijst, \& Tartwijik, 2009), and in the Gulf region (Parahoo et al., 2013), where both the culture and climate are considerably different from those of the Southeast Asian countries. Hence, the generalizability of their findings to the context of the present study is arguable. Additionally, studies concerning student satisfaction in the context of the Malaysian higher education, particularly those relating to international postgraduate students, are rather limited.

The key objective of this paper is to conduct a comprehensive review of the literature and to conceptually develop a student satisfaction model, which integrates several antecedents that are theoretically linked to the satisfaction of international postgraduate students. Most of the previous studies focused on the internal learning environment as the major predictor of student satisfaction, and studies pertaining to the external learning environment, particularly with regards to student satisfaction, seem rather limited. Hence, it is recommended (e.g., Arambewela \& Hall, 2013; LeBlanc \& Nguyen, 1999) that scholars explore student satisfaction beyond the factors of the internal environment.

Previous studies have also highlighted that the feedback provided by research supervisors is a contributory factor to student satisfaction (Kleijn et al., 2013; Todd, Bannister, \& Clegg, 2004). Feedback benefits learning and achievement at all levels of education, across all content areas (Black \& Wilaim, 1998). In an empirical study, Pyhalto, Stubb, and Lonka (2009) observed that supervisors' feedback was significantly linked to low stress and anxiety, which contributes to a high level of satisfaction. In the case of higher education, considering that students are the best judges, it is imperative that their satisfaction be assessed on a regular basis (Jalali et al., 2011).

The present paper integrates both the internal and external learning environments, and supervisor feedback in a conceptual model of major antecedents to student satisfaction. The proposed model suggests that the internal and external environment of a university, along with the feedback provided by research supervisors, are the key factors that influence the level of satisfaction among international postgraduate students.

\section{Literature Review}

\subsection{Student Satisfaction}

Fornell et al. (1996) described satisfaction as "an overall feeling or as satisfaction with elements of the transaction". Although satisfaction has been an accepted global construct for predicting consumer behaviour, the term is also well-accepted in academic research (Parahoo et al., 2013). Being a service organization, higher learning institutions consider students as customers, or the 'major stakeholders' who are involved in the purchase of higher education programmes and services (Ravindran \& Kalpana, 2012).

Student satisfaction can be subjective to the students themselves, in terms of how well a learning environment supports their academic achievements (Lo, 2010, p. 47). From the perspective of international students, student satisfaction refers to their satisfaction with their overall educational experience, which reflects their primary goal of obtaining their educational qualification from the host country (Arambewela \& Hall, 2013, p. 973). Satisfaction helps students to build their self-confidence, which, ultimately, leads to the development of useful skills and the acquisition of knowledge (Letcher \& Neves, 2010). Decreased student attrition and enhanced student experience are also the major outcomes of student satisfaction (Fearn, 2008; Trotter \& Roberts, 2006).

Studies (e.g., Arambewela \& Hall, 2013; Li, 2005) have indicated that student satisfaction intensely depends on 
the quality of the services provided. Hence, satisfaction of international postgraduate students can be conceptualized through different key aspects, such as internal and external university environment, and supervisors' feedback. More recently, Ibrahim et al. (2014) investigated the determining factors of student satisfaction in skill-based training institutions in the Klang Valley, Malaysia. The results showed that a campus environment that is conducive for learning was the most significant predictor of student satisfaction.

To summarize, it is broadly accepted that student satisfaction is important for universities to retain their current students, and, potentially, attract new ones. Moreover, the external and internal learning environment and supervisors' feedback can be the key antecedents to achieving a higher level of satisfaction among international postgraduate students.

\subsection{Internal Environment}

The internal environment includes the quality of education, reputation of the institution, student facilities and post-study marketability of a degree, all of which strongly influence the students' level of satisfaction (Arambewela, Hall, \& Zuhair, 2006). Since international students are highly concerned about their study outcomes and future careers (Zepke \& Leach, 2007), teaching quality (quality of research supervision for postgraduate students) is considered to be a critical factor for student satisfaction. The supervision of research has been defined as the "most responsible task undertaken by an academic" (Armstrong, 2004; Burnett, 1977), "the most complex and subtle form of teaching" (Brown \& Atkins, 1988, p. 115), and 'the most advanced level of teaching" (Connell, 1985). The quality of research supervision has been described as the major element affecting the quality of research students (Trigwell \& Dunbar-Goddet, 2005).

Zhao (2012) asserted that student satisfaction has a strong relationship with the quality of higher education perceived by the student, and that this perception will be influenced by many factors concerning the educational service, including expectation of service and image of the institution. Likewise, according to Li (2005), an institution's image and learning quality significantly affect the satisfaction of students among the postgraduate business school students in the US and UK. This finding is in line with that of Kuo and Ye (2009) who found that internal environmental factors, such as service quality and institution's image, were the key aspects that influenced the level of student satisfaction; in fact, these factors also enhanced the students' academic performance. Concisely, besides quality education, postgraduate international students also valued the reputation of the institution, which, ultimately leads to a higher level of satisfaction.

\subsection{External Environment}

External environment refers to "the social and physical dimensions outside of the university campus in which a student spends a significant amount of their academic life, engaged in multiple actions with host community" (Arambewela \& Hall, 2013, p. 974). The "host community" in this context refers to the local community groups related to a particular institution in which a student lives, along with other local and international students (Arambewela \& Hall, 2013). Previous studies on social relationships (such as friendship patterns, housing and other accommodation facilities) have found that international students who successfully formed social ties with their local communities have reported higher satisfaction (e.g., Gracia-Aracil, Gabaldon, Mora, \& Villa, 2009; Sam, 2009). Past studies have also shown that international students prefer to spend more than sixty per cent of their academic tenure with students of the same country (Ward \& Masgoret, 2004). This is comparable with the Social Identity Theory (Tajfel \& Turner, 1979), which professes that individuals will strive to maintain their positive self-esteem through group membership. In respect of housing and accommodation facilities, studies have associated better housing arrangements with quality of life. For instance, Amole (2009) argued that one's satisfaction with accommodation facilities and housing can lead to a higher satisfaction with a high quality of life.

Arambewela and Hall (2013), who investigated student satisfaction in several Australian universities located in the state of Victoria, conceptualized and examined different antecedents of student satisfaction, such as a university's internal learning environment, the community (external learning environment) and personal values (in terms of self-efficacy and hedonism). The findings showed a significant relationship between "students' internal and external learning environments" and their satisfaction formation process. It was also found that the external learning environment has a great impact on the internal learning environment (university) and student satisfaction. This confirms that the external learning environment in terms of the community is a critical factor that influences the satisfaction of international students. Although Arambewela and Hall's study considered international postgraduate students as units of analysis, it overlooked aspects relating to research supervision. 


\subsection{Supervisor's Feedback}

Past studies (e.g., Arambewela \& Hall, 2013) conceptualized feedback as one of the dimensions of the internal learning environment; however, they exclusively focused on either the foundation or undergraduate level of investigation. Therefore, it is argued that the relationship between a postgraduate student and their supervisor is a one-to-one relationship, which differs from lecturer-student relationships at other levels (e.g., foundation, undergraduate). Hence, there is a need to conceptualize and assess feedback (supervisory feedback in this case) separately rather than as a sub-component of the internal environment. Given these points, supervisor feedback is discussed as a standalone construct in this paper.

Research supervision is considered as an important contributory factor to the success or failure of a postgraduate student. It refers to a complex social encounter between the two parties who are involved in converging and diverging interests (Ismail, Abiddin, \& Hassan, 2011). Most studies (e.g., Kleijn et al., 2013; Maggs, 2014; Mainhard et al., 2009) identified the role of the different aspects of research supervision, particularly of a supervisor's feedback. Generally, a supervisor's feedback has not only been associated with the achievement of quality research outcomes, but also with the higher level of student satisfaction (Alam et al., 2013). Feedback refers to the "spoken or unspoken response from others in response to behaviour" (Falchikov, 1995). Although a few scholars have agreed on the critical role of a supervisor's feedback, others have argued that students are not always interested in receiving feedback (Duncan, 2007; Murtagh \& Baker, 2009). Notwithstanding, the National Union of Students (NUS, 2008) suggested that the importance of feedback depends largely on its quality (cited in Maggs, 2014). From the perspective of a research student, Denicolo (2004) asserted that research supervisors should consistently provide feedback to their supervisees, in order for the former to improve the quality of their supervision.

As Race (2005) pointed out, there are several methods of giving feedback, such as verbal, written, self-assessment and peer-assessment. Currently, audio, electronic and video are considered as the novel methods of giving feedback (Maggs, 2014). Interestingly, other scholars, including Brown and Glover (2006), found that written feedback is the most favored form of feedback. Their findings are comparable with the results of Lee and Schallert (2008), who reported that written feedback was more effective in the more trusting student-teacher relationships. In another study, Murtagh and Baker (2009) reported that students are equally engaged in both written and oral communications. A number of studies have also found a significant relationship between student satisfaction and the feedback they received. For instance, the National Student Survey of Scotland reported that 48 per cent of Scottish students agreed that feedback had helped them to clarify the areas in which they were lacking, in addition, these students also explicitly indicated their level of satisfaction following the feedback they received (Buckley, 2012).

Based on the discussion above, a graphical explanation is drawn (Figure 1) to depict the proposed conceptual model. Drawing on an in-depth review of the past studies, this framework suggests that a university's internal environment (education quality and image), external environment (accommodation and life style) and research supervisor feedback (quality and quantity) are the key factors that sustain or improve the level of satisfaction of international postgraduate students in Malaysia's higher learning institutions.

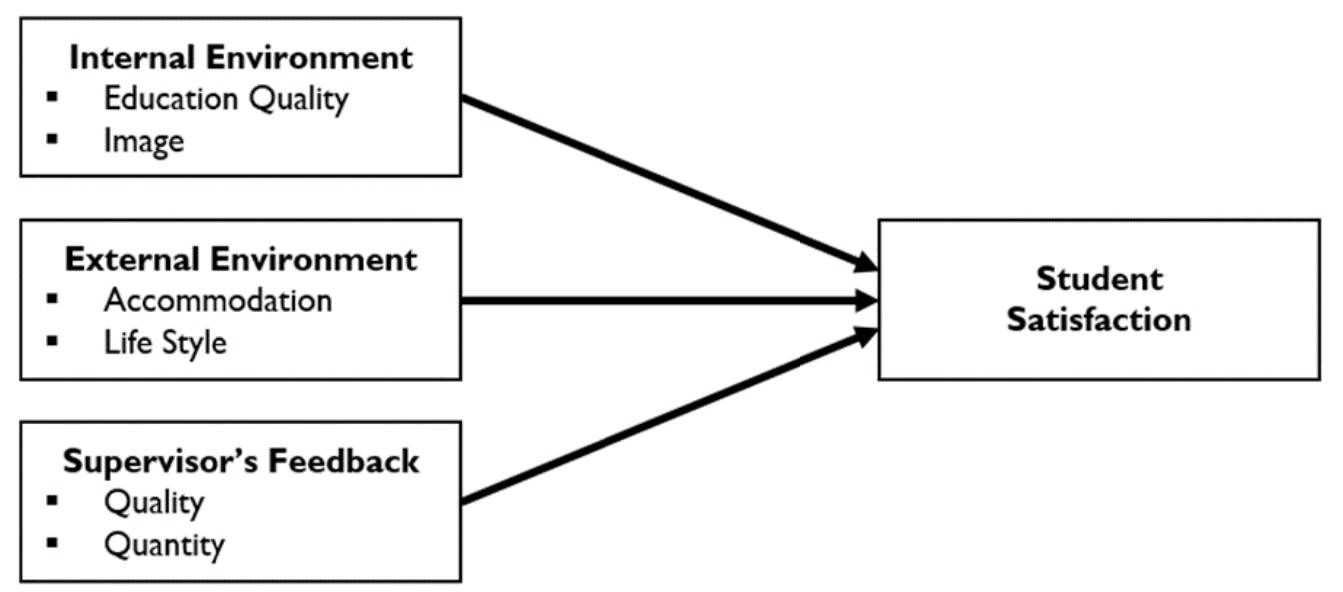

Figure 1. Proposed conceptual framework of the study 


\section{Conclusion}

The higher education sector in Malaysia is now experiencing a competitive and commercial environment due to the increasing number of public and private learning institutions. As students have more choice, it is imperative that the education industry not only attracts new students, but also retains the current ones. Thus, it is crucial for the Malaysian higher learning institutions to pay greater attention to student satisfaction. Based on a thorough review of past studies, this paper indicates that student satisfaction intensely depends on the quality of the services provided. Hence, a framework is proposed, which conceptualizes that the internal and external environment of a university, and the feedback of research supervisors, are the major contributors to the satisfaction of international postgraduate students.

When students receive quality education, and perceive the renowned image of the institution to which they belong, they will likely feel proud and secure in respect of their future careers. This will eventually lead them to a higher level of satisfaction. The external environment also plays a vital role in improving student satisfaction. For example, international students like to spend most of their time with other social groups and the community to which they belong. These social interactions provide opportunities for international students to broaden their knowledge and improve the level of satisfaction. Finally, it is suggested that the supervisor's feedback is vital to achieve the anticipated level of student satisfaction. This is critical, as past studies have indicated that feedback improves the level of student satisfaction.

Limited effort has been made to conceptualize and explore student satisfaction in the Malaysian higher learning institution setting. Hence, this paper intends to enrich the understanding of researchers and academicians concerning the topic, while highlighting the potential antecedents that may not only facilitate the achievement of student satisfaction, but also attract potential customers. Future studies could include other possible dimensions of the internal and external environment to extend the proposed model further. Given that research supervisors play an important role in ensuring the successful and timely completion of a thesis, further studies may consider several other supervisory dimensions, such as personality traits, knowledge sharing, and demographic variables (age, gender, experience, ethnicity), to investigate their linkages with the satisfaction of international postgraduate students. In addition, it is recommended that future researchers validate the proposed framework with the use of advanced statistical methods, such as structural equation modeling, to obtain robust results.

\section{References}

Alam, F., Alam, Q., \& Rasul, M. G. (2013). A pilot study on postgraduate supervision. Paper presented at the 5th BSME International Conference on Thermal Engineering, Bangladesh.

Amole, D. (2009). Residential satisfaction and levels of environment in students' residences. Environment and Behaviour, 41(6), 1-14. http://dx.doi.org/10.1177/0013916508322175

Anderson, E. W., \& Fornell, C. (2000). Foundations of the American customer satisfaction index. Journal of Total Quality Measurement, 11(7), 869-882. http://dx.doi.org/10.1080/09544120050135425

Arambewela, R., \& Hall, J. (2008). A model of student satisfaction: International postgraduate students from Asia. European Advances in Consumer Research, 8, 129-135.

Arambewela, R., \& Hall, J. (2013). The international effects of the internal and external university environment, and the influence of personal values, on satisfaction among international postgraduate students. Studies in Higher Education, 38(7), 972-988. http://dx.doi.org/10.1080/03075079.2011.615916

Arambewela, R., Hall, J., \& Zuhair, S. (2006). Postgraduate International Students from Asia: Factors Influencing Satisfaction. Journal of Marketing for Higher Education, 15(2), 105-127. http://dx.doi.org/10.1300/J050v15n02_05

Armstrong, S. J. (2004). The impact of supervisors' cognitive styles on the quality of research supervision in management education. British Journal of Educational Psychology, 74, 599-616.

Black, P., \& Wilaim, D. (1998). Assessment and classroom learning. Assessment in Education, 5(1), 7-74.

Brown, G., \& Atkins, M. (1988). Effective teaching in higher education. London: Methuen.

Brown, G., \& Glover, C. (Eds.). (2006). Evaluating written feedback. Oxon: Routledge.

Buckley, A. (2012). National Student Survey: Analysis of national results for 2011 Scotland.

Burnett, R. (1977). Supervision of higher degree students-problem areas and possible solutions Report of the vice chancellor's committee on research and postgraduate study (Vol. 3, pp. 153-165). University of Queensland: Higher Education Research and Development. 
Connell, R. (1985). How to supervise PhDs. The Australian Universities' Review, 28(2), 38-41.

Crotts, J. C., Mason, P. R., \& Davis, B. (2009). Measuring guest satisfaction and competitive positioning in the hospitality and tourism industry. Journal of Travel Research, 48, 139-151. http://dx.doi.org/10.1177/0047287508328795

Denicolo, P. (2004). Doctoral supervision of colleagues: Peeling off the veneer of satisfaction and competence. Studies in Higher Education, 29(6), 693-707.

Duncan, N. (2007). Feed Forward: Improving students' use of tutors' comments Assessment and Evaluation in Higher Education, 32(3), 271-283. http://dx.doi.org/10.1080/02602930600896498

Edvantage Asia One. (2011). Malaysia's pull factors as an education hub, Edvantage Asia One. Retrieved from $\mathrm{http}: / / \mathrm{www}$.edvantage.com.sg/content/malaysias-pull-factors-education-hub

Elliot, K. M., \& Healey, M. A. (2001). Key factors influencing student satisfaction related to recruitment and retention. Journal of Marketing for Higher Education, 10(4), 1-11. http://dx.doi.org/10.1300/J050v10n04_01

Falchikov, N. (1995). Improving feedback to and from students. London: Kogan Page.

Fearn, H. (2008). Living the dream. Times Higher Education, 11(17), 862.

Fornell, C., Johnson, M. D., Anderson, E. W., Cha, J., \& Bryant, B. E. (1996). The American customer satisfaction index: Nature, purpose and findings. Journal of Marketing, 60, 7-18.

Gracia-Aracil, A., Gabaldon, D., Mora, J. G., \& Villa, L. E. (2009). The relationship between life goals and field of study among young European graduates. Higher Education, 53(6), 843-865. http://dx.doi.org/10.1007/s10734-005-7517-3

Horany, A. A., \& Hassan, S. A. (2011). Marital adjustment among postgraduate students at universities in Malaysia. Elixir Psychology, 37, 3773-3776.

Ibrahim, M. Z., Rahman, M. N. A., \& Yasin, R. M. (2014). Determining Factors of Students' Satisfaction with Malaysian Skills Training Institutes. International Education Studies, 7(6), 9-24. http://dx.doi.org/10.5539/ies.v7n6p9

Ismail, A., Abiddin, N. Z., \& Hassan, A. (2011). Improving the Development of Postgraduates' Research and Supervision. International Education Studies, 4(1), 78-89. http://dx.doi.org/10.5539/ies.v4n1p78

Jalali, A., Islam, M. A., \& Ariffin, K. H. K. (2011). Service Satisfaction: The Case of a Higher Learning Institution in Malaysia. International Education Studies, 4(1), 182-192. http://dx.doi.org/10.5539/ies.v4n1p182

Kleijn, R. A. M. D., Meijer, P. C., Pilot, A., \& Brekelmans, M. (2013). The relation between feedback perceptions and the supervisor-student relationship in master thesis project. Teaching in higher education, $1-14$.

Kuo, Y. K., \& Ye, K. D. (2009). The causal relationship between service quality, corporate image and adults' learning satisfaction and loyalty: A study of professional training programmes in a Taiwanese vocational institute. Total Quality Management, 20(7), 749-762. http://dx.doi.org/10.1080/14783360903037085

LeBlanc, G., \& Nguyen, G. (1999). Listening to customer's voice: Examining perceived service value among business college students. International Journal of Educational Management, 11(2), 72-79. http://dx.doi.org/10.1108/09513549910278106

Lee, G., \& Schallert, D. L. (2008). Meeting in the margins: Effects of the teacher-student relationship on revision processes of EFL college students taking a composition course. Journal of Second Language Writing, 17, 165-182. http://dx.doi.org/10.1016/j.jslw.2007.11.002

Letcher, D. W., \& Neves, J. S. (2010). Determinant of undergraduate business student satisfaction. Research in Higher Education Journal, 1-26.

Li, W. M. (2005). A comparative study between UK and USA: The student satisfaction in higher education and its influential factors. Journal of Marketing Management, 21, 859-878. http://dx.doi.org/10.1362/026725705774538471

Lizzio, A., Wilson, K., \& Symons, R. (2002). University students' perceptions of the learning environment and academic outcomes: Implications for theory and practice. Studies in Higher Education, 27(1), 27-52. http://dx.doi.org/10.1080/03075070120099359 
Lo, C. C. (2010). How student satisfaction factors affect perceived learning. Journal of the Scholarship of Teaching and Learning, 10(1), 47-54.

Maggs, L. A. (2014). A case study of staff and student satisfaction with assessment feedback at a small specialised higher education institution. Journal of further and higher education, 38(1), 1-18. http://dx.doi.org/10.1080/0309877X.2012.699512

Mainhard, T., Rijst, R. V. D., \& Tartwijik, J. V. (2009). A model for the supervisor-doctoral student relationship. High Educ, 58, 359-373.

Murtagh, L., \& Baker, N. (2009). Feedback to feed forward: Student response to tutors' written comments and assignments. Practitioner Research in Higher Education, 3(1), 20-28.

NUS. (2008). Education information: Feedback on assessment.

Parahoo, S. K., Harvey, H. L., \& Tamim, R. M. (2013). Factors influencing student satisfaction in universities in the Gulf region: Does gender of student matter? Journal of Marketing in Higher Education, 1-20. http://dx.doi.org/10.1080/08841241.2013.860940

Pyhalto, K., Stubb, J., \& Lonka, K. (2009). Developing scholary communities as learning environments for doctoral students. International Journal for Academic Development, 14(3), 221-232. http://dx.doi.org/10.1080/13601440903106551

Race, P. (2005). Marking learning happen. London: SAGE.

Ravindran, S. D., \& Kalpana, M. (2012). Student's Expectation, Perception and Satisfaction towards the Management Educational Institutions. Procedia Economics and Finance, 2, 401-410. http://dx.doi.org/10.1016/s2212-5671(12)00102-5

Sam, D. (2009). Satisfaction with life among international students. Social Indicators Research, 53, 315-337. http://dx.doi.org/10.1023/A:1007108614571

Symons, R. (2006). In their own words: Finding out what students think about their university experience. Synergy, 23, 31-34.

Tajfel, H., \& Turner, J. C. (Eds.). (1979). An integrative theory of intergroup conflict. Monterey CA: Brooks/Cole.

Temizer, L., \& Turkyilmaz, A. (2012). Implementation of Student Satisfaction Index Model in Higher Education

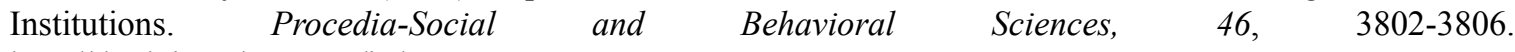
http://dx.doi.org/10.1016/j.sbspro.2012.06.150

Ting, K. (2000). A multi-level perspective on student ratings of instructions: Lessons from the Chinese experience. Research in Higher Education, 41(5), 637-661. http://dx.doi.org/10.1023/A:1007075516271

Todd, M., Bannister, P., \& Clegg, S. (2004). Independent inquiry and the undergraduate dissertation: Perceptions and experiences of final-year social science students. Assessment and evaluation in higher education, 29(3), 335-355. http://dx.doi.org/10.1080/0260293042000188285

Trigwell, K., \& Dunbar-Goddet, H. (2005). The Research Experience of Postgraduate Research Students at the University of Oxford. University of Oxford.

Trotter, E., \& Roberts, C. A. (2006). Enhancing the early student experience. Higher Education Research and Development, 25(4), 371-386.

Ward, C., \& Masgoret, A. M. (2004). The experiences international students in New Zealand. Reports on the results of of the national survey. Wellington: International Policy and Development Unit, Minstry of Education, New Zealand Government.

Yousif, Y. M., \& Chelliah, S. (2010). Adjustment in international students in Malaysian public university. International Journal of Innovaiton, Management and Technology, 1(3), 275-278. Retrieved from http://repo.uum.edu.my/id/eprint/2487

Zepke, N., \& Leach, L. (2007). Improving student outcomes in higher education: New Zealand teachers' view on teaching students from diverse backgrounds. Teaching in Higher Education, 12(5), 6. http://dx.doi.org/10.1080/13562510701596190.

Zhao, X. (2012). A Review on Service Quality and Student Satisfaction of Higher Education Soft Computing in Information Communication Technology, 115-122. http://dx.doi.org/10.1007/978-3-642-29148-7_17 


\section{Copyrights}

Copyright for this article is retained by the author(s), with first publication rights granted to the journal.

This is an open-access article distributed under the terms and conditions of the Creative Commons Attribution license (http://creativecommons.org/licenses/by/3.0/). 